\title{
Evaluation of low concentration glyphosate effect on horseradish peroxidase enzyme activity
}

\author{
VALDIR E. Olivo* \\ Andrea Tansini* \\ Rafael H. Martello ${ }^{* \dagger}$ \\ Renan de Souza Rezende* \\ Daniel Albeny Simões* \\ J. Vladimir Oliveira ${ }^{\dagger}$ \\ Marcio Antônio Fiori ${ }^{*}$ \\ Jacir Dal Magro*
}

\begin{abstract}
Among several pesticides used in agriculture, glyphosate herbicide is one of the most employed in crop fields in spite of its recognized toxic effects on human health and on the environment. Consecutive use of glyphosate in crops can cause significantly increase the severity of various diseases, reduced growth, impaired defenses and alter the physiology of plants affecting the susceptibility or tolerance to diseases. Peroxidase enzymes play an important role in some physiological and pathological processes, involving active oxygen species occurring at the level of plasma membrane and cell wall. The aim of this work was to evaluate the effect of glyphosate on the enzymatic activity of horseradish peroxidase. For this purpose, tests were conducted to determine the optimal $\mathrm{pH}$ range and then reaction kinetic where was added, the substrate (catechol), mediator $\left(\mathrm{H}_{2} \mathrm{O}_{2}\right)$, glyphosate and enzyme (horseradish peroxidase), varying the substrate concentration glyphosate to assess the activity of this reaction and the influence of herbicide on the enzyme activity. Results demonstrate that glyphosate increases the activity of horseradish peroxidase in low concentration and can decrease the resistance of the plant to the entry of pathogens.
\end{abstract}

Keywords: Glyphosate; Herbicides; Horseradish peroxidase; Enzyme activity.

\footnotetext{
* Environmental Sciences Area, Unochapecó, PO Box 1141, Chapecó, SC, Brazil.

$\dagger$ Department of Chemical and Food Engineering, UFSC, Florianópolis, SC, 88040-900, Brazil.
} 


\section{GLyphosATE EFFECT ON ENZYME ACTIVITY}

\section{InTRODUCTION}

pesticides are largely employed in agriculture for phytosanitary control, to increase field productivity and to assure food production. Among several herbicides used in agriculture, glyphosate is undoubtedly one of the most applied (BAIRD \& CANN, 2012). Glyphosate, formely N- (phosphonomethyl) glycine, a post-emerging herbicide, classified as non selective with systemic action, showing great elimination efficiency against invading plants (CARLISLE \& TREVORS, 1988). It presents three polar groups (carboxyl, amino and phosphonate) that strongly combine with metallic ions, especially transition ones (DANIELE et al., 1997; SANCHÍS et al., 2012).

While glyphosate has benefits related to increased agricultural productivity, on the other hand, recent studies have demonstrated deleterious effects on the environment, human health and the crop plant where it is applied (GASNIER et al., 2009; PÉREZ et al., 2011; MESNAGE et al., 2015). Recent studies demonstrate the adverse effects of glyphosate on human health and also on the environment (CUHRA et al. 2016) For instance, the exposure to Roundup, even at low dosages for a short time period, may induce to serious hematological injuries, presumably caused by an increase in the oxidative stress (MODESTO \& MARTINEZ, 2010; SANCHÍS et al., 2012; THONGPRAKAISANG et al., 2013). Long time exposure to glyphosate in contaminated soil or water, even at low concentrations may lead to serious problems to human health such as anemia, oxidative stress associated diseases, like cancer and neurodegenerative diseases (MINK et al., 2012).

Small concentrations of glyphosate can cause changes in population and microbial activity of the soil. ARAÚJO et al. (2003) detected an increase of $10-15 \%$ found an increase of $10-15 \%$ in the $\mathrm{CO} 2$ evolved and a 9-19\% increase in fluorescein diacetate (FDA) hydrolyses in the presence of glyphosate compared to the same type of soil which had never received glyphosate. Consecutive use of glyphosate in crops can cause significantly increase the severity of various diseases, reduced growth, impaired defenses and alter the physiology of plants affecting the susceptibility or tolerance to diseases (FERNANDEZ ET AL., 2009; JOHAL \& HUBER, 2009; YAMADA et al., 2009), which leads to the use of other types of pesticides that may further harm the environment and the health of the final consumers of this crop. When plants are attacked by pathogens, they trigger a complex defense mechanism that may be related to structural barriers, molecules stored in cells that have different types of biological activity, synthesis of protease inhibitors in tissues or even inducing enzymes such as peroxidases (ALMAGRO et al., 2009).

Studies show that peroxidase enzymes play an important role in some physiological and pathological processes, involving active oxygen species (ROS) as hydrogen peroxide $\left(\mathrm{H}_{2} \mathrm{O}_{2}\right)$ and superoxide anion $\left(\mathrm{O}_{2}{ }^{-}\right)$, occurring at the level of plasma membrane and cell wall (VIANELLO \& MACRI, 1991). Active oxygen species, including superoxide, hydrogen peroxide, and the hydroxyl radical, could potentially affect many cellular processes involved in plant/ 
pathogen interactions (SHARMA et al., 2012). Oxygen peroxide $\left(\mathrm{H}_{2} \mathrm{O}_{2}\right)$ molecule with half-life of only $1 \mathrm{~ms}$ and forms in the plant in many situations of stress and the variation of its concentration interferes directly in the defense system of the plant against pathogens (BHATTACHARJEE, 2012; SHARMA et al., 2012).

Peroxidase catalyzes the reactions of oxidoreduction between $\mathrm{H}_{2} \mathrm{O}_{2}$ and reduces, participates in physiological processes in plants, such as lignification, formation and crosslinking of cell wall components, auxin catabolism, senescence, protection against attack of pathogens, insects and abiotic stressors (BAKER \& ORLANDi, 1995; ALMAGRO et al. 2009; BHATTACHARJEE, 2012). The activation of this enzyme can significantly alter these processes making the plant more susceptible to pathogens attack. The aim of this work was to evaluate the effect of glyphosate on the enzymatic activity of horseradish peroxidase in laboratory conditions.

\section{MATERIAL AND METHODS}

\subsection{Chemicals and reagents}

Reagents utilized for analyzes were catechol PA $\left(\mathrm{C}_{6} \mathrm{H}_{6} \mathrm{O}_{2}\right)$, concentration of $0.005 \mathrm{M}, \mathrm{H}_{2} \mathrm{O}_{2} 30 \%(\mathrm{w} / \mathrm{v})$, monohydrated monobasic sodium phosphate PA $\left(\mathrm{NaH}_{2} \mathrm{PO}_{4} \mathrm{H}_{2} \mathrm{O}\right)$, sodium acetate $\left(\mathrm{CH}_{3} \mathrm{COONa}\right)$, glacial acetic acid PA $\left(\mathrm{C}_{2} \mathrm{H}_{4} \mathrm{O}_{2}\right)$, all of them from Vetec (Brazil). Sodium phosphate $12 \mathrm{H}_{2} \mathrm{O}$ PA $\left(\mathrm{Na}_{2} \mathrm{HPO}_{4} 12 \mathrm{H}_{2} \mathrm{O}\right)$ for buffer preparation was purchased from Fmaia (Brazil).
A standard $1000 \mathrm{mg} \mathrm{L}^{-1}$ glyphosate (purchased from Fluka Analytical Germany) solution was prepared. A $6 \mathrm{M}$ sodium hydroxide $(\mathrm{NaOH})$ solution was prepared and sulfuric acid $\left(\mathrm{H}_{2} \mathrm{SO}_{4}\right) \mathrm{PA}$ were from Vetec (Brazil). The HRP was from Sigma Aldrich (USA) and a solution of $2 \mathrm{mg}$ $\mathrm{mL}^{-1}$ was prepared.

\subsection{Enzyme kinetic assays}

From the UV spectra it was possible to determine the wavelength for which the enzyme reached the best performance, 410 $\mathrm{nm}$. Reaction UV readings was carried out for $1 \mathrm{~min}$ at each $5 \mathrm{sec}$. The absorbance resulting from the appearance of $o$-quinone was used to determine the initial reaction velocity $\left(\mathrm{V}_{\text {init }}\right) \quad(\mathrm{DA} / \mathrm{Dt})$. The molar absorptivity of quinone is $1,623\left(\mathrm{M}^{-1} \mathrm{~cm}^{-1}\right)$.

To determine the kinetic parameters, three concentrations of glyphosate were used $\left(3.33 ; 8.33\right.$ and $\left.166.67 \mu \mathrm{g} \mathrm{L}^{-1}\right)$ and five for catechol $(0.33 ; 0.67 ; 1.00 ; 1.33$ and $1.67 \mathrm{mM}$ ). All kinetics were added $100 \mu \mathrm{L}$ of $\mathrm{H}_{2} \mathrm{O}_{2}(9.791010-3 \mathrm{M})$ and $200 \mu \mathrm{L}$ of enzymatic extract (the optimum values). The production of $o$-quinona was quantified and analyzed by the the Lineweaver-Burk $\left(1 / \mathrm{V}_{\text {init }} \times 1 /[\mathrm{S}]\right)$ plot method, which is an algebraic transformation of the MichaelisMenten equation, being the regression analysis used to determine $\mathrm{K}_{\mathrm{m}}$ and $\mathrm{V}_{\max }$ at each substrate concentration. The $\mathrm{pH}$ of the reaction medium was kept at 7 thanks to the use of $100 \mu \mathrm{L}$ of $\mathrm{H}_{2} \mathrm{O}_{2}\left(9.791010^{-3} \mathrm{M}\right)$ and $200 \mu \mathrm{L}$ of enzymatic extract (the optimum values). After the construction of the enzymatic curve, it was added increasing concentrations of glyphosate $(10,25,50$ and $100 \mu \mathrm{L})$. 


\subsection{Effect of $\mathrm{pH}$ on the activity of HRP determination}

To determine the optimum $\mathrm{pH}$, analysis was carried out for solutions in the range of 3 to 9 . In a glass cuvette it was added 500 $\mu \mathrm{L}$ of catechol $(5.0 \mathrm{mM}), 100 \mu \mathrm{L}$ of $\mathrm{H}_{2} \mathrm{O}_{2}$ $\left(9.791010^{-3} \mathrm{M}\right) 200 \mu \mathrm{L}$ of enzyme and completed to $2.2 \mathrm{~mL}$ of buffer at varying $\mathrm{pH}$ tested: acetate buffer $(\mathrm{pH} 3,4$ and 5), phosphate buffer ( $\mathrm{pH} 6$ and 7), and ammonium buffer ( $\mathrm{pH} \mathrm{8,9}$ and 10). All assays were accomplished in triplicate.

\section{Results and Discussion}

In general, the optimum $\mathrm{pH}$ for most enzymes ranges from 6 to 8 , but there are exceptions. It is known that there exists a hydrogenionic concentration which allows certain protonated and deprotonated arrangements that leads the enzyme molecule to an ideal conformational so as to exert its catalytic role. Of course, this will also depend on the number and type of ionizing groups that the enzyme exhibit, i.e., it depends on its primary structure (KIST, 2014). According to the current literature related to HRP, the optimum $\mathrm{pH}$ is in the range of $6.0-7.5$ and it has been shown that the enzyme is more stable from 5 to 9 (JIANG et al., 2014).

From the results presented in Fig. 1 it is clear that the best $\mathrm{pH}$ situates in the range of 6 - 9, being the maximum enzyme activity verified at $\mathrm{pH}$ equal to 8 , nevertheless, here the $\mathrm{pH}$ was set to 7 .

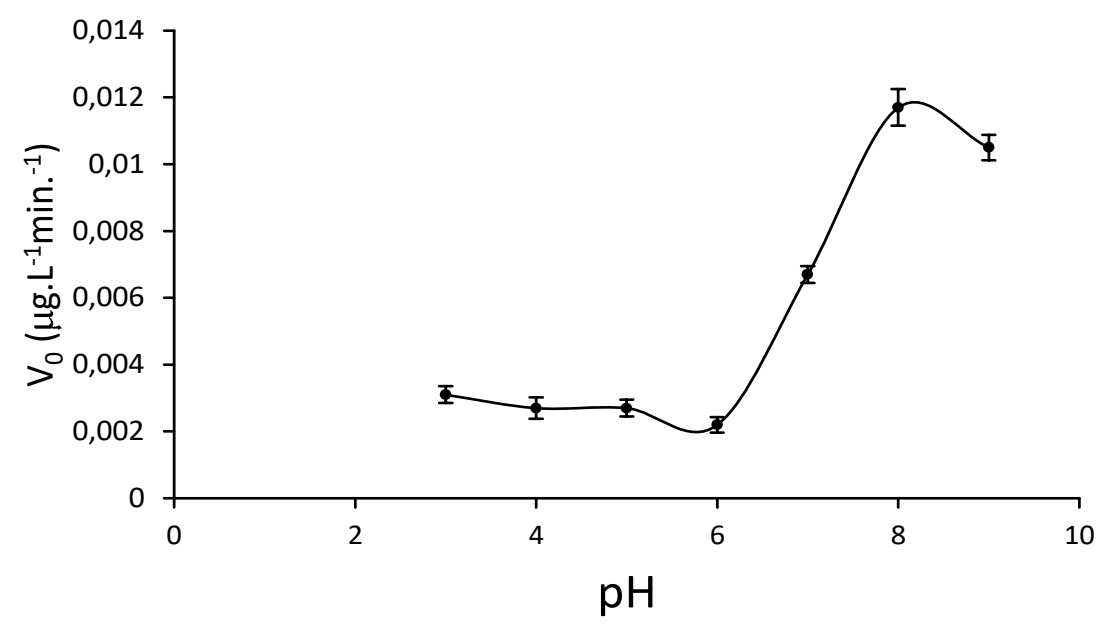

Figure 1: Effect of $p H$ on the activity of HRP.

Figure 2 shows the initial reaction rate of 1,2-benzoquinone formation for different initial concentrations of catechol (substrate) in the reaction catalyzed by HRP in the presence of varying contents of glyphosate, where it can be seen that the initial reaction rate increases as the substrate concentration increases up to a saturation point approximately $1.0 \mathrm{mM}$ $\mathrm{L}^{-1}$ of catechol substrate. Above this value, a nearly asymptotic behavior is noted for all glyphosate concentrations approaching the maximum reaction rate where enzyme molecules present themselves as enzymesubstrate (ES) complexes, in which the enzyme concentration becomes irrelevant 


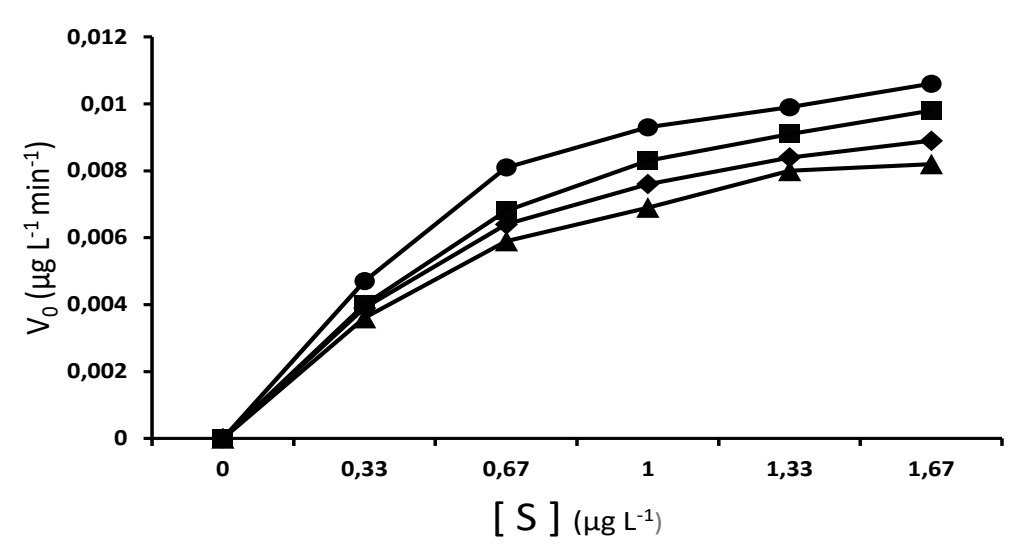

Figure 2: Effect of glyphosate on the initial velocity of reaction, without $(\mathbf{\Delta})$, and with $3.33(\bullet) 8.33$

(-) and $166.67 \mu \mathrm{g}$-1 of glyphosate $(\bullet)$ at different substrate concentration, $\mathrm{pH}=7$ and $25^{\circ} \mathrm{C}$.

and hence the reaction enters in a steadystate condition.

It should also be noted that though not much pronounced a raise in glyphosate concentration leads to an increase in the initial reaction rate, hence pointing that an improve in the enzyme catalytic activity in the presence of glyphosate. Such behavior is different from that found by (Songa et al. 2009), who reported glyphosate as a inhibitor agent of HRP enzyme. In a reaction catalyzed for enzyme, the raise in the inhibitors concentration can cause a decrease in the initial reaction rate due to the inhibition action of a certain compound over the enzyme activity. In the present case however, as observed in Fig. 3, the opposite was verified as there was no enzyme inhibition by glyphosate, and in fact an increase in enzyme activity was noticed.

Figure 3 shows the Lineweaver-burk plot, in fact an algebraic arrangement of

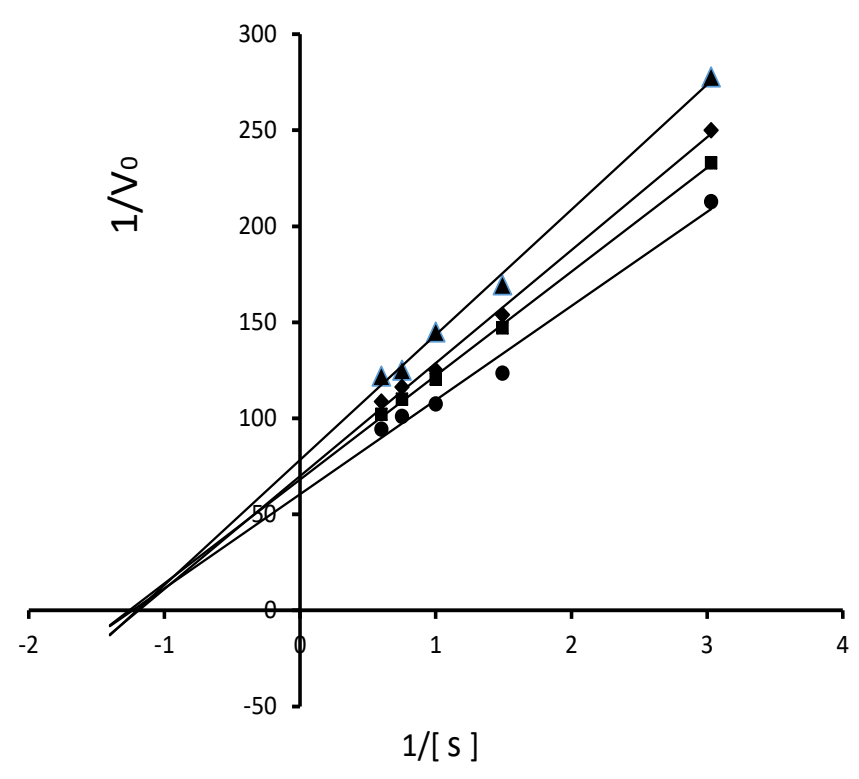

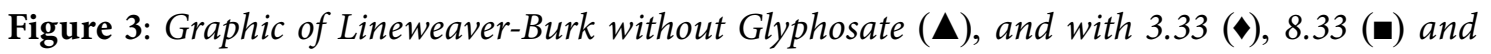
166.67 $\mu \mathrm{g}$ L-1 of glyphosate (•). 
Michaelis-Menten, relating $1 / \mathrm{V}_{0}$ and $1 /$ [S]. The curve presented for the reaction without glyphosate resulted in a maximum initial velocity lower than the velocities for the other concentrations of the pesticide. Clearly, it can be seen from this figure that the maximum reaction velocity is altered with increasing glyphosate concentration. Nevertheless, $K_{m}$ values are practically not sensitive to glyphosate, showing that glyphosate does not alter the affinity of the enzyme for the substrate, probably due to the high affinity of the enzyme for catechol (NOKTHAI et al., 2010).

From the Lineweaver-Burk plot it was determined the maximum reaction rate values $\left(\mathrm{V}_{\max }\right)$ and $\mathrm{K}_{\mathrm{m}}$ at different glyphosate concentrations, as shown in Table 1. It can be observed from this table that $\mathrm{V}_{\text {max }}$ values increase as glyphosate concentration increases, hence contributing to an enhancement of the enzyme activity.

Glyphosate molecule presents three ligand groups - amino, carboxylate and phosphoate, which make it a strong chealant agent, especially for transition metals in neutral $\mathrm{pH}$ for deprotonation of both carboxylate and phosphate groups. SUBRAMANIAM \& HOGGARD (1988) showed that glyphosate make a strong chemical bond with $\mathrm{Fe}^{+3}$ ion forming a stable complex which iron as coordinating atom in the form of tetrahedron ligand. Thus, it should be expected that as HRP is a metal-enzyme, whose active site possess $\mathrm{Fe}^{+3}$, and when at the fundamental state

Table 1: $\quad V_{\max }$ and $K_{m}$ of the enzymatic kinetics at different glyphosate concentrations.

\begin{tabular}{ccc}
\hline Glyphosate $\left(\mu \mathrm{g} . \mathrm{L}^{-1}\right)$ & $\mathbf{V}_{\max }\left(\boldsymbol{\mu g} \cdot \mathrm{L}^{-1} \cdot \mathbf{m i n}\right)$ & $\mathbf{K}_{\mathrm{m}}\left(\boldsymbol{\mu g} \cdot \mathrm{L}^{-1}\right)$ \\
\hline 0 & 0.012 & 0.8321 \\
3.33 & 0.0137 & 0.8197 \\
8.33 & 0.0138 & 0.7773 \\
166.67 & 0.0165 & 0.8107 \\
\hline
\end{tabular}

glyphosate binds somehow to this metal ion and affects the oxidation reaction catalyzed by HRP enzyme (ALMAGRO et al., 2009).

The production of free radicals is continuously regulated by the antioxidant defense system in health organisms. Nevertheless, herbicides like glyphosate induceoxidativestressand/oranimpairment of the antioxidant defensive mechanisms (DE AGUIAR et al., 2016; JOHAL \& HUBER, 2009). Therefore, characterization of the activity of xenobiotic metabolizing enzymes is useful to monitor the effects of pesticide exposure. Different studies have showed that glyphosate exposure triggers protective mechanisms, affecting different xenobiotic-metabolizing enzymes (LARSEN et al., 2014). Cyanobacteria Microcystis aeruginosa exposed for $48 \mathrm{~h}$ to glyphosate showed increased concentration of malondialdehyde and enhanced activities of superoxide dismutase, catalase and peroxidase. Also, glyphosate induced apoptosis of and triggered toxin release in M. aeruginosa (WU et al., 2016).

In overall, our results showed that glyphosate increases the enzymatic activity of horseradish peroxidase even at low concentrations. Although the mechanism of glyphosate action on the activity of the 
HRP enzyme is not clear, the fact that this enzyme is involved in important physiological processes in plants, such as lignification, formation and reticulation of cell walls, among others, make evident that this accelerating effect may be directly related to the greater vulnerability of plant pathogens exposed to this herbicide even at low concentrations (KRENCHINSKI et al. 2017; ZOBIOLE et al. 2010a; ZOBIOLE et al. 2010b).

\section{CONCLUSIONS}

The plot of enzyme behavior showed that the optimum $\mathrm{pH}$ for HRP enzyme is in the range of 7-9. Values for the initial reaction rate, $V_{0}$, increase for increasing substrate concentration, with saturation tendency for cathecol concentration above $1.0 \mathrm{mM} \mathrm{L}^{-1}$. Results obtained in this work show that glyphosate increases the enzyme activity horseradish peroxidase increasing the maximum initial reaction rate at low concentrations and may decrease the resistance of the plant to the entry of pathogens.

\section{Acknowledgements}

This study was supported by Coordenação de Aperfeiçoamento de Pessoal de Nível Superior (CAPES), Fundação de Amparo à Pesquisa de Santa Catarina (FAPESC), and Unochapecó. The funders had no role in study design, data collection and analysis, decision to publish, or preparation of the manuscript.

\section{REFERENCES}

ALMAGRO L. et al. Class III peroxidases in plant defence reactions. Journal of Experimental Botany. v.60, n.2, p.377390, 2009. doi:10.1093/jxb/ern277

ARAÚJO A. S. F. et al. Effect of glyphosate on the microbial activity of two Brazilian soils. Chemosphere V. 52 p.799-804, 2003. doi: 10.1016/S00456535(03)00266-2

BAIRD, C.; CANN, M. Chapter 13: Pesticides In: BAIRD, C.; CANN, M. Environmental Chemistry $5^{\text {th }}$ ed. New York: Freeman and Company, 2012.

BAKER, C. J.; ORLANDI, E. W. Active oxygen in plant pathogenesis. Annual review of phytopathology v.33 p. 299-321, 1995. doi: 10.1146/annurev. py.33.090195.001503

BHATTACHARJEE, S. The Language of Reactive Oxygen Species Signaling in Plants. Journal of Botany. v.2012: p.122, 2012. doi: 10.1155/2012/985298

CARLISLE, S. M.; TREVORS, J. T. Glyphosate in the environment - (Review Article). Water, Air, and Soil Pollution. v.39, p.409-420, 1988. doi: 10.1007/ BF00279485

CUHRA, M. et al. Glyphosate: Too Much of a Good Thing? Frontiers in Environmental Science. v.4 p.1-14, 2016. doi: 10.3389/fenvs.2016.00028

DNIELE, P. G. et al. Copper(II) complexes of $\mathrm{N}$-(phosphonomethyl)glycine in aqueous solution: A thermodynamic and spectrophotometric study. Talanta v.45, p.425-431, 1997. doi: 10.1016/S00399140(97)00156-2 
DE AGUIAR, L. M. et al. Glyphosate-based herbicide exposure causes antioxidant defence responses in the fruit fly Drosophila melanogaster. Comparative Biochemistry and Physiology Part - C: Toxicology and Pharmacology. v.185186, p.94-101, 2016. doi: 10.1016/j. cbpc.2016.03.006

FERNANDEZ, M. R. et al. Glyphosate associations with cereal diseases caused by Fusarium spp. in the Canadian Prairies. European Journal of Agronomy. v.31, p.133-143, 2009. doi: 10.1016/j.eja.2009.07.003

GASNIER, C. et al. Glyphosate-based herbicides are toxic and endocrine disruptors in human cell lines. Toxicology. v.262, p.184-191, 2009. doi: 10.1016/j.tox.2009.06.006

JIANG, Y. et al. Enzyme-based inverse opals: a facile and promising platform for fabrication of biocatalysts. Chemical Communications v.50, p.5490-5493, 2014. doi: 10.1039/C4CC01721H

JOHAL, G. S.; HUBER, D. M. Glyphosate effects on diseases of plants. European Journal of Agronomy v.31, p.144-152, 2009. doi: 10.1016/j.eja.2009.04.004

KIST, T. L. Structure and Catalysis: enzymes In: NELSON, D. L.; COX, M. M. Lehninger principles of biochemistry, 6th edition. New York: Freeman and Company. 2014.

LARSEN, K. et al. Effects of Sublethal Exposure to a Glyphosate-Based Herbicide Formulation on Metabolic Activities of Different Xenobiotic-Metabolizing Enzymes in Rats. International journal of toxicology. v.33, p.307-318, 2014. doi: $10.1177 / 1091581814540481$
MESNAGE, R. et al. Potential toxic effects of glyphosate and its commercial formulations below regulatory limits. Food and Chemical Toxicology v.84, p.133-153, 2015. doi: 10.1016/j. fct.2015.08.012

MINK, P. J. et al.(2012) Epidemiologic studies of glyphosate and cancer: A review. Regulatory Toxicology and Pharmacology. v.63, p.440-452, 2012. doi: 10.1016/j.yrtph.2012.05.012

MODESTO, K. A.; MARTINEZ, C. B. R. Roundup ${ }^{\varpi}$ causes oxidative stress in liver and inhibits acetylcholinesterase in muscle and brain of the fish Prochilodus lineatus. Chemosphere. v.78, p.294-299, 2010. doi: 10.1016/j.chemosphere.2009.10.047

NOKTHAI, P. et al. Molecular modeling of peroxidase and polyphenol Oxidase: Substrate specificity and active site comparison. International Journal of Molecular Sciences. v.11, p.3266-3276, 2010. doi: 10.3390/ijms11093266

PÉREZ, G. L. et al. Effects of Herbicide Glyphosate and Glyphosate-Based Formulations on Aquatic Ecosystems. Herbicides and the Environment. p.343-368, 2011. doi: ISBN: 978-953307-476-4

SANCHÍS, J. et al. Determination of glyphosate in groundwater samples using an ultrasensitive immunoassay and confirmation by on-line solidphase extraction followed by liquid chromatography coupled to tandem mass spectrometry. In: Analytical and Bioanalytical Chemistry. v. 402, p.2335-2345, 2012. doi: 10.1007/s00216011-5541-y 
SHARMA, P. et al. Reactive Oxygen Species, Oxidative Damage, and Antioxidative Defense Mechanism in Plants under Stressful Conditions. Journal of Botany. v.2012 p.1-26, 2012. doi: $10.1155 / 2012 / 217037$

SINHORIN, V. D. G. et al. Effects of the acute exposition to glyphosate-based herbicide on oxidative stress parameters and antioxidant responses in a hybrid Amazon fish surubim (Pseudoplatystoma sp). Ecotoxicology and Environmental Safety. v.106, p.181-187, 2014. doi: 10.1016/j.ecoenv.2014.04.040

SONGA,E.A.etal.Electrochemicaldetection of glyphosate herbicide using horseradish peroxidase immobilized on sulfonated polymer matrix. Bioelectrochemistry. v.75, p.117-123, 2009. doi: 10.1016/j. bioelechem.2009.02.007

SUBRAMANIAM, V.; HOGGARD, P. E. Metal Complexes of Glyphosate. Journal of agricultural and food chemistry. v.36, p.1326-1329, 1988. doi: 10.1021/ jf00084a050

THONGPRAKAISANG, S. et al. Glyphosate induces human breast cancer cells growth via estrogen receptors. Food and Chemical Toxicology. v.59, p.129-136, 2013. doi: 10.1016/j.fct.2013.05.057
VIANELLO, A.; MACRI, F. Generation of superoxide anion and hydrogen peroxide at the surface of plant cells. Journal of Bioenergetics and Biomembranes. v.23, p.409-423, 1991. doi: 10.1007/BF00771012

WU, L. et al. Physiological effects of the herbicide glyphosate on the cyanobacterium Microcystis aeruginosa. Aquatic Toxicology. v.178, p.72-79, 2016. doi: 10.1016/j. aquatox.2016.07.010

YAMADA, T. et al. Glyphosate interactions with physiology, nutrition, and diseases of plants: Threat to agricultural sustainability? European Journal of Agronomy. v.31, p.111-113, 2009. doi: 10.1016/j.eja.2009.07.004

ZOBIOLE, L. H. S. et al. Glyphosate affects lignin content and amino acid production in glyphosate-resistant soybean. Acta Physiologiae Plantarum. v.32, p.831-837 2010a. doi: 10.1007/ s11738-010-0467-0

ZOBIOLE, L. H. et al. Water use efficiency and photosynthesis of glyphosateresistant soybean as affected by glyphosate. Pesticide Biochemistry and Physiology. v.97, p.182-193, 2010b. doi: 10.1016/j.pestbp.2010.01.004 